\title{
Levetirasetam Kullanan Epilepsili Bir Çocuk Hastada Hipertransaminaseminin Nadir Bir Nedeni: Salmonella Hepatiti
}

\author{
A Rare Cause of Hypertransaminasemia in a Child with Epilepsy \\ Taking Levetiracetam: Salmonella Hepatitis
}

Mina MISIRLIGIL ${ }^{1}$, Melike ARSLAN² ${ }^{2}$ Necati BALAMTEKIN²

'SBÜ, Gülhane Tıp Fakültesi, Çocuk Sağlığı ve Hastalıkları Anabilim Dalı, Ankara, Türkiye

${ }^{2}$ SBÜ, Gülhane Tıp Fakültesi, Çocuk Sağlığı ve Hastalıkları Anabilim Dalı, Çocuk Gastroenteroloji Bilim Dalı, Ankara, Türkiye

\begin{abstract}
öz
Salmonella hepatiti, salmonella enteritinin karaciğeri tutmasılla oluşan bir enfeksiyon hastalığı olup akut gastroenterit bulguları ve hipertransaminazemi ile seyreder. Levetirasetam, GABA-glisin sistemini aktive ederek antiepileptik etki gösteren yeni nesil bir antiepileptik ajandır ve nadiren hipertransaminazemiye yol açabilmektedir. Epilepsi tanısıyla 15 aydır levetirasetam kullanmakta olan 11 yaşında bir kız hasta, bulantı-kusma, ateş, karın ağrısı şikayetleriyle birlikte hipertransaminazemi saptanması nedeniyle başvurdu. Salmonella hepatiti tanısı konulan hastada uygun antibiyoterapi ile klinik bulgular gerilemesine rağmen hipertransaminazeminin devamlılı̆ı gözlendi. Persistan hipertransaminazemi etiyolojisi araştıııldı. Etiyolojide salmonella hepatitinin yanı sıra levetirasetam kullanımının yer aldığı görüldü ancak hasta ilaç kesilmeden izlendi. Salmonella enfeksiyonunu takiben 12. haftada normal karaciğer enzim seviyelerine ulaşıldı. Sonuç olarak, levetirasetam kullanan, akut gastroenterit ve hepatit bulgularıla getirilen hastalarda ilaç tedavisi kesilmeden önce salmonella hepatitinin de ayıııcı tanıda düşünülmesi gerektiği değerlendirilmektedir.
\end{abstract}

Anahtar Sözcükler: Hipertransaminazemi, Levetirasetam, Salmonella

\begin{abstract}
Salmonella hepatitis is an infectious disease caused by liver involvement of salmonella enteritis and characterized by acute gastroenteritis and hypertransaminasemia. Levetiracetam is a new generation antiepileptic agent that activates the GABA-glycine system and may rarely cause hypertransaminasemia. An 11-year-old girl with epilepsy who had been taking levetiracetam for 15 months was consulted because of hypertransaminasemia with nausea-vomiting, fever and abdominal pain. The patient was diagnosed with salmonella enteritis. The clinical findings regressed with appropriate antibiotherapy but hypertransaminasemia lasted. The etiology of persistent hypertransaminasemia has been investigated. In addition to salmonella hepatitis, the use of levetiracetam was seen as causes but the drug was not discontinued. Normal liver enzyme levels were reached in the 12th weeks following Salmonella infection. Consequently, it is considered that before discontinuation of medication, salmonella hepatitis may be in differential diagnosis in patients who have acute gastroenteritis and hepatitis findings and also receiving levetiracetam.
\end{abstract}

Key Words: Hypertransaminasemia, Levetiracetam, Salmonella

Çıkar Çatışması / Conflict of Interest: : Tüm yazarlar adına, ilgili yazar çıkar çatışması olmadığııı belirtir. 0000-0002-7922-5514 Finansal Destek / Financial Disclosure: Yazarlar bu olgu için finansal destek almadılklarnı beyan etmișlerdir. 0000-0002-0107-4699 $0000-0001-8665-5611$

Onay / Confirmation: Kayıt sırasında veliler tarafından araştırmaya katıım için bilgilendirilmiş bir onay imzalanmıştır.

Atıf yazım şekli / How to cite : Mısırlıgil M, Arslan M, Balamtekin N. Levetirasetam Kullanan Epilepsili Bir Çocuk Hastada Hipertransaminaseminin Nadir Bir Nedeni: Salmonella Hepatiti. Türkiye Cocuk Hast Derg 2021:15:162-164.
Yazışma Adresi / Correspondence Address:

MiNA MISIRLIGiL

SBÜ, Gülhane Tıp Fakültesi,

Çocuk Sağıı̆ı ve Hastalıkları Anabilim Dalı, Ankara, Türkiye, Türkiye

E-posta: drmisirligil@gmail.com
Geliş tarihi / Received : 22.02.2020 Kabul tarihi / Accepted : 14.07.2020 Elektronik yayın tarihi $\quad: 20.10 .2020$ Online published

DOI: 10.12956/tchd.692952 


\section{Giriș}

Salmonella, intestinal lenf dokuda hücre içi olarak çoğalarak ateş ile birlikte diyare, kabızlık, halsizlik, karın ağrısı gibi semptomlara yol açan bir bakteriyel enfeksiyondur. Hastalığın seyri sırasında nadiren mikroorganizmanın karaciğer, dalak gibi iç organlara ve kemiğe yayılımı görülmektedir (1).

Bu makalede, epilepsi tanısıyla 15 aydır levetirasetam kullanmakta olan 11 yaşında bir kIz hastada gelişen akut gastroenterit ve hipertransaminazemi kliniği sunulmuş ve literatür bilgileri ışı̆̆ında tartışılmıştır.

\section{OLGU SUNUMU}

On bir yaşında kız hasta beş gündür devam eden bulantı, kusma ve ishal yakınmaları ile acil servise getirilmiş ve burada yapılan incelemelerde subfebril ateş, akut mukozal tip ishal ve hipertransaminazemi saptanarak Çocuk Gastroenterolojisi polikliniğine yönlendirilmiştir.

Hastanın öyküsünde on sekiz ay önce epilepsi tanısı aldığı, üç ay sodyum valproat kullandığı ancak ilaca yeterli yanıt alınamaması nedeniyle levetirasetam tedavisine geçildiği ve on beş aydır bu ilacı kullandığı öğrenildi. Hastanın epilepsi dışında bilinen başka hastalığı bulunmamaktaydı. Soy geçmişinde özellik yoktu.

Fizik incelemesinde vücut ağırlığı 57 kg (\%90-97), boy 160 cm (\%90-97) olup vital bulguları; vücut sıcaklı̆ı $36.5^{\circ} \mathrm{C}$, kalp tepe atımı 88/dk (60-100 atım /dk), solunum sayısı 17 /dk (14-22 /dk) ve arteriyel kan basıncı 110/70 mmHg (100-120/60-75 $\mathrm{mmHg}$ ) olarak ölçüldü.

Tanıya yönelik yapılan laboratuvar incelemelerinde hemoglobin $13.4 \mathrm{~g} / \mathrm{dll}$, beyaz küre $12000 / \mathrm{mm}^{3}$, trombosit 256.000/ $\mathrm{mm}^{3}$, INR 1.04, c-reaktif protein (CRP), $8.51 \mathrm{mg} / \mathrm{dl}(0-5 \mathrm{mg} /$ dl)'di. Rutin biyokimyasal incelemesinde aspartat transaminaz (AST) $197 \mathrm{U} / \mathrm{L}$ (15-35 U/L), alanin aminotransferaz (ALT) 266U/L (7-35 U/L), gama glutamil transferaz (GGT) 217 $\mathrm{U} / \mathrm{L}$ (0-38 U/L), laktat dehidrogenez (LDH) $306 \mathrm{U} / \mathrm{L}$ (0-247 U/L) olarak ölçüldü, diğer parametreler normal sınılardaydı. Gaita mikroskopik incelemesinde her sahada 5-6 lökosit saptandı ve gaita kültüründe Salmonella suşu üredi. Hastanın mevcut şikâyetlerinin salmonella enfeksiyonu nedeniyle olduğu değerlendirilerek, antibiyogramda mikroorganizmanın trimetoprim-sulfametoksazole duyarlı olması nedeniyle hastaya on gün süreyle trimetoprim-sülfametaksazol tedavisi verildi. Antibiyoterapinin üçüncü gününden itibaren hastanın tüm klinik şikâyetlerinde belirgin gerileme görüldü, akut faz reaktanları normal aralığa geriledi ancak AST, ALT artarak (336 U/L, $329 \mathrm{U} / \mathrm{L}$ sırasılla) seyretti. Tedavi sonrası enzim yüksekliği devam ettiği için hasta hepatite neden olabilecek diğer hastallılar yönünden de incelendi. Viral hepatitlere yönelik yapılan incelemelerde hepatit A,B,C ve HIV antikorları negatifti. Toksoplazma, CMV, EBV ve Rubella antikor titreleri non-reaktifti. Etiyolojiye yönelik yapılan incelemelerde lgA $126 \mathrm{mg} / \mathrm{dl}$ (referans aralı 70-400 $\mathrm{mg} / \mathrm{dll})$, doku transglutaminaz IgA negatif, doku transglutaminaz IgG negatif, seruloplazmin 26 mg/gün (2-60 mg/gün), 24 saatlik idrarda bakır $65 \mathrm{mg} / \mathrm{dl}(22-58 \mathrm{mg} / \mathrm{dl})$ saptandı. Otoimmün taramada ANA, anti ds DNA, ASMA, AMA, LKM-1, ANCA negatifliği görüldü. Tiroid fonksiyon testleri normaldi. Metabolik tarama amaciyla idrarda keton, tandem kitle spektrometrisi, idrarda organik asitler, idrarda redüktan madde tarandı ancak önem arz eden bir bulgu saptanmadı. Hastanın alfa 1 anti tripsin düzeyi $153 \mathrm{mg} / \mathrm{dL}$ (110-280 mg/dL), alfa fetoprotein düzeyi 3.44 $\mathrm{ng} / \mathrm{mL}(0-9 \mathrm{ng} / \mathrm{mL})$ ve ferritin $25.7 \mathrm{ng} / \mathrm{mL}$ (11-306.8 ng/mL)'di. Radyolojik incelemelerden ultrasonografik görüntülemede minimal steatoz, karaciğer uzun çapı $14 \mathrm{~cm}(8.5-14 \mathrm{~cm})$ ve safra kesesi içinde lümenin yarısından fazlasını dolduran multipl milimetrik taşlar izlendi. MRCP görüntülemede safra kesesi lümeninde multipl milimetrik taşlar izlendi, karaciğer boyutu 153 mm olarak ölçüldü. Hipertransaminazeminin altıncı haftada devam etmesi üzerine karaciğer biyopsisi yapıldı. Biyopside minimal portal ödem, venüler konjesyon ile parankimde ve portal alanda seyrek lenfositler görüldü. İmmünohistokimyasal/ histokimyasal olarak parankimde birikim saptanmadı ve fibrozis bulgusu izlenmedi. Bu bulgular ilaç toksisitesine özgül olmasa da hastanın mevcut hepatit tablosunun levetirasetam tedavisiyle ilişkili olabileceği ve anti-epileptik tedavisinde revizyona gidilmesi düșünülürken, hastanın ilk bașvurusundan on iki hafta sonra AST, ALT ve GGT değerlerinin normale dönmesi $(18,12,13$ $U / L)$ üzerine levetirasetam tedavisi sürdürüldü.

\section{TARTIŞMA}

Salmonella hepatiti nadir görülen bir hastalık olup kliniğe bulantıkusma, diyare, ateș, hepatomegali, karın ağrısı, sarılık, baş ağrısı ve rölatif bradikardi ile yansımaktadır. Daha nadir olarak konstipasyon ve splenomegali görülebilmektedir (2). Salmonella hepatitinde transaminaz düzeylerinin hastalığın 2-3. haftalarında yükseliş gösterdiği, uygun antibiyotik tedavisini takiben iki veya üçüncü haftada klinik bulguların iyileşip, transaminaz düzeylerinin normale gerilediği bildirilmektedir $(3,4)$. Hastaların üçte ikisinden fazlasında AST düzeyinin ALT düzeyinden daha fazla yükseldiği belirtilmektedir (2). Ülkemizden sunulan erişkin iki vakada ALT düzeylerinin AST düzeylerinden daha yüksek olduğu bildirilmiştir (5). Hastamızın klinik bulguları, literatürde bildirilen olgularla uyumluydu. Serum ALT düzeyleri daha önce ülkemizde bildirilen iki olgu gibi AST düzeylerine göre daha yüksekti.

Levetirasetam, sinaptobrevin 2a'ya tutunarak nöronların hipersenkronizasyonunu inhibe ederek, GABA-glisin sistemini aktive ederek antiepileptik etki göstermektedir. Levetirasetamın en bilinen yan etkileri nazofarenjit, sinirlilik, somnolans, 
asteni/yorgunluk ve baş dönmesi olarak sıralanabilir (6). Hiperpigmentasyon, trombositopeni, lökopeni, anemi ve rabdomiyoliz ise olgu bazında bildirilen nadir yan etkileridir (79). Levetirasetamın karaciğer enzim düzeylerine etki etmemesi, klasik anti-epileptiklerden üstünlüğü olarak belirtilmektedir (10). Bununla birlikte, literatürde hipertransaminazemiye yol açtığı nadir olgular vardır. Levatirasetam kullandıktan bir süre sonra ALT yüksekliği daha belirgin olmak üzere hipertransaminazemi geliştiği ve ilacı kesmeyi takiben altıncı haftada transaminaz düzeylerinin normale gerilediği saptanmıştır (11,12). Sunduğumuz olguda da hipertransaminazemi paterni benzer şekildeydi fakat sürenin 12 haftaya kadar uzadığı görüldü. Persistan hipertransaminazemi bakımından etiyolojik değerlendirme yapıldı ancak neden saptanamadı. Nadir de olsa levetirasetamın hipertransaminazemi yaptığı göz önüne alındı ancak son değerlendirmede enzim düzeylerinin normale gerilemesi üzerine hipertansaminazemi levatirasetam kullanımı ile ilişkilendirilmedi.

Sonuç olarak; bulantı-kusma, ishal, ateş, karın ağıısı gibi akut gastroenterit bulgulariyla birlikte hipertransaminazemisi olan çocuk hastalarda ayıııcı tanıda nadir görülen bir hastalık olan salmonella hepatiti de düșünülmelidir. Sunulan vakada salmonella hepatitine sekonder hipertransaminazeminin on iki haftaya kadar uzayabileceği ve hipertransaminazemi nedeni olarak doğrudan ilaçların suçlanmaması ve gereksiz yere tedavinin kesilmemesi gerekliliği değerlendirilmektedir.

\section{KAYNAKLAR}

1. Bhatti,JM, Memon Y, Sarfaraz S,Salahuddin N. An Unusual Case of Extensively Drug Resistant Typhoid Fever. Cureus 2019;1:e4664.

2. El-Newihi HM, Alamy ME, Reynolds TB. Salmonella hepatitis: Analysis of 27 cases and comparison with acute viral hepatitis. Hepatology 1996;24:516-9.

3. Pramoolsinsap C, Viranuvatti V. Salmonella hepatitis. J Gastroenterol Hepatol 1998;13:745-50.

4. Khosla SN. Typhoid hepatitis. Postgrad Med J 1990;66:923-5.

5. Vatansev C, Gölcük M, Hüseyin Y, Pamukçu A. Salmonella hepatiti: Tıkanma sarılığı ile karışan iki olgu. Genel Tıp Derg 2003;13:131-4.

6. Verrotti A, Prezioso G, Sabatino FD, Franco V, Chiarelli F, Zaccara G. The adverse event profile of levetiracetam: A meta-analysis on children and adults. Seizure 2015;31:49-55.

7. Algahtani H, Marghalani S, Satti M, Shirah B. LevetiracetamInduced Skin Hyperpigmentation: An Extremely Rare Undesirable Side Effect. J Epilepsy Res 2017;7:106-8.

8. Alzahrani T, Kay D, Algahtani SA, Makke Y, Lesky L, Koubeissi MZ. Levetiracetam-induced pancytopenia. Epilepsy Behav. Case Reports 2015;4:45-7.

9. Rastogi V, Singh D, Kaur B, Arora P,Gadikota JP. Rhabdomyolysis: A Rare Adverse Effect of Levetiracetam. Cureus 2018;10:8-11.

10. Bölükbași N, Akar F, Bır S. Antiepileptik Illaçların Lipit Profili ve Karaciğer Enzimleri Üzerine Etkisi. Noro psikiatri Arsivi 2011;48:116.
11. Sethi NK, Sethi PK, Torgovnick J, Arsura E, Cukierwar F. Asymptomatic elevation of liver enzymes due to levetiracetam: A case report. Drug Metabol. Drug Interact 2013;28:123-4.

12. Rachamallu V, Song MM, Reed JM, Aligeti M. Levetiracetaminduced transaminitis in a young male with traumatic brain injury. Oxford Med Case Reports 2017;2017:omx067. 